\title{
Density-Functional-Theory Calculations of Formation Energy of the Nitrogen-Doped Diamond
}

\author{
Sholihun ${ }^{\star}$, Hana Pratiwi Kadarisman, and Pekik Nurwantoro \\ Department of Physics, Faculty of Mathematics and Natural Sciences, Universitas Gadjah Mada, \\ Sekip Utara, Yogyakarta 55281, Indonesia
}

Received July 20, 2017; Accepted February 22, 2018

\begin{abstract}
The geometry optimization of the nitrogen-doped diamond has been carried out by the density functional theory (DFT) calculations. The defective diamond of substitutional and interstitial nitrogen atoms are modeled by using a simple-cubic supercell. Atoms in the supercell are relaxed by allowing them to move so that the atomic forces are less than $5.0 \times 10^{-3} \mathrm{eV} / \AA$. The formation energy is calcuated, which is $10.89 \mathrm{eV}$ for the substitutional defect. The convergence of the calculation is checked with respect to the $k \times k \times k$ - Monkhorst-Pack grids. The calculated energy difference between $k=4$ and 6 is very small $(7.0 \mathrm{meV})$. The calculation is also evaluated by using a 216-sites supercell. It is found that the energy difference is $0.10 \mathrm{eV}$. Thus, the calculations of the formation energy converge well. As for the interstitial defect, some possible configurations are modeled and find that the smallest formation energy is $21.88 \mathrm{eV}$. Therefore, the most stable configuration of the nitrogen-doped diamond belongs to the substitutional site.
\end{abstract}

Keywords: formation energy; diamond; nitrogen doping

ABSTRAK

Optimasi geometri dari intan dengan doping nitrogen telah dilakukan dengan menggunakan Density Functional Theory (DFT). Sistem cacat pada intan berupa substitusional dan insterstisial nitrogen dimodelkan dengan menggunakan supercell bertipe simple-cubic. Atom-atom dalam supercell direlaks dengan mengijinkan atom-atom tersebut bergerak sedemikian sehingga gaya-gaya atomic lebih kecil dari $5.0 \times 10^{-3} \mathrm{eV} / A$. Kemudian energi formasi dihitung untuk sistem subsitusional dan interstisial. Energi formasi subsitusional diperoleh sebesar 10,89 eV. Cek konvergensi perhitungan dilakukan dengan melakukan varisasi $k \times k \times k$ - Monkhorst-Pack grids. Dari hasil yang diperoleh dapat ditunjukkan bahwa perbedaan energi antara $k_{M P}=4$ and 6 sangat kecil (7,0 meV). Selanjutnya perhitungan dicek untuk supercell yang lebih besar yang terdiri dari 216 atom dan diperoleh perbedaan energi hanya $0,10 \mathrm{eV}$. Dengan demikian, perhitungan energi formasi konvergen. Untuk sistem interstisial, beberapa konfigurasi dimodelkan dan diperoleh bahwa energi formasi terkecil sebesar 21,88 eV. Sehingga dapat disimpulkan bahwa konfigurasi yang paling stabil untuk sistem intan dengan doping nitrogen adalah konfigurasi substitusional.

Kata Kunci: energi formasi; intan; doping nitrogen

\section{INTRODUCTION}

Diamond is one of the allotropes of carbon, which is transparent because of the absence of light adsorption. Defect introductions in diamond can make it adsorb light to produce colored material [1-3]. Like in other crystals, defects in diamond can be a vacancy, atomic interstitial, substitution, or impurity (dopant) defect with the very common dopant in diamond is nitrogen [4-6]. Recently, the study of defective diamond has attracted much attention because of its broad applications in technology such as for active materials of ultrafast electronic devices [7-9] and in jewelry industries [1-3].
To model a defective system, a theoretical approach based on the density functional theory (DFT) is frequently conducted since DFT can successfully reproduce the experimental results [10-13]. In the previous theoretical studies, it was shown that borondoped diamond produces the blue-colored diamond, and nitrogen-doped diamond yields to the yellow one [1]. Meanwhile, the germanium-vacancy defects have strong photoluminescence band, which could be a good candidate as the active material in quantum cryptography and quantum information devices $[7,14-$ 15]. The nitrogen-doped diamond was studied in the frame of the DFT [16-17]. Lombardi et al. and Deak et al. calculated the diamond with nitrogen atoms impurity

* Corresponding author.

DOI: 10.22146/ijc.26785

Email address : sholihun@ugm.ac.id

Sholihun et al. 
and they found that the outward relaxation occurs in the final geometry. The present study focuses on the calculation of the formation energy and geometry distortions of the substituted and interstitial nitrogen atom in diamond.

In this study, supercells consisting of 64 atomic sites are used to model the nitrogen-doped diamond. The stability of configurations of the system is evaluated by calculating the formation energies. The lower formation energy results in more stable configuration. The convergence of the formation energy is checked concerning the $k$-point mesh grids. Furthermore, a higher supercell consisting of 216 sites is applied to show the reliability of the supercell size.

\section{COMPUTATIONAL METHOD}

The DFT calculations were performed by employing the generalized gradient approximation (GGA) in the first-principles code PHASE [18], which implements the plane wave ultrasoft-pseudopotential basis set. In these calculations, a 9 Ry cutoff energy was applied. PHASE is computational code employing quantum mechanics used to calculate electronic structure of materials in the crystal phase. To get the optimized lattice constant, total energies were calculated with respect to the cell volumes and fit the data by using the Birch-Murnaghan equation of states (BM EOS) [19, 20], given in Eq. 1:

$E(V)=E_{0}+\frac{9 V_{0} B_{0}}{16}\left\{\left[\left(\frac{V_{0}}{V}\right)^{\frac{2}{3}}-1\right]^{3} B_{0}^{\prime}+\left[\left(\frac{V_{0}}{V}\right)^{\frac{2}{3}}-1\right]^{2}\left[6-4\left(\frac{V_{0}}{V}\right)^{\frac{2}{3}}\right]\right\}$

where $E_{0}, V_{0}, B_{0}$, and $B_{0}^{\prime}$ are curve-fitting parameters, which are minimum energy, cell volume at $E_{0}$, bulk modulus at $\mathrm{V}_{0}$, and first-derivative of the bulk modulus at $V_{0}$, respectively. The accurate fitting-result of the lattice parameter calculations of the perfect diamond is shown in Fig. 1. The calculated lattice constant is obtained to be $3.59 \AA$, which is very close to the experimental value of $3.57 \AA$ [21] and previous DFT study of $3.58 \AA$ [22].

The defective system is modeled by introducing substitutional and interstitial nitrogen atoms in the perfect diamond crystal. The substitutional defect is formed by replacing one carbon atom in the center of the supercell by a nitrogen atom while the interstitial one is formed by adding a nitrogen atom in several sites (Fig. 3). Carbon has four valence electrons so that it has four nearest-neighbor atoms, while nitrogen has three valence electrons. In this case, nitrogen is isolated in the tetrahedral defect volume formed by four carbon atoms.

Three approaches of relaxations in the substitutional sites were performed dubbed as $A_{1}, A_{2}$, and $A_{3}$, which are relaxation by considering up to first-nearest neighbor atoms (Fig. 2(a)), relaxation by considering up to

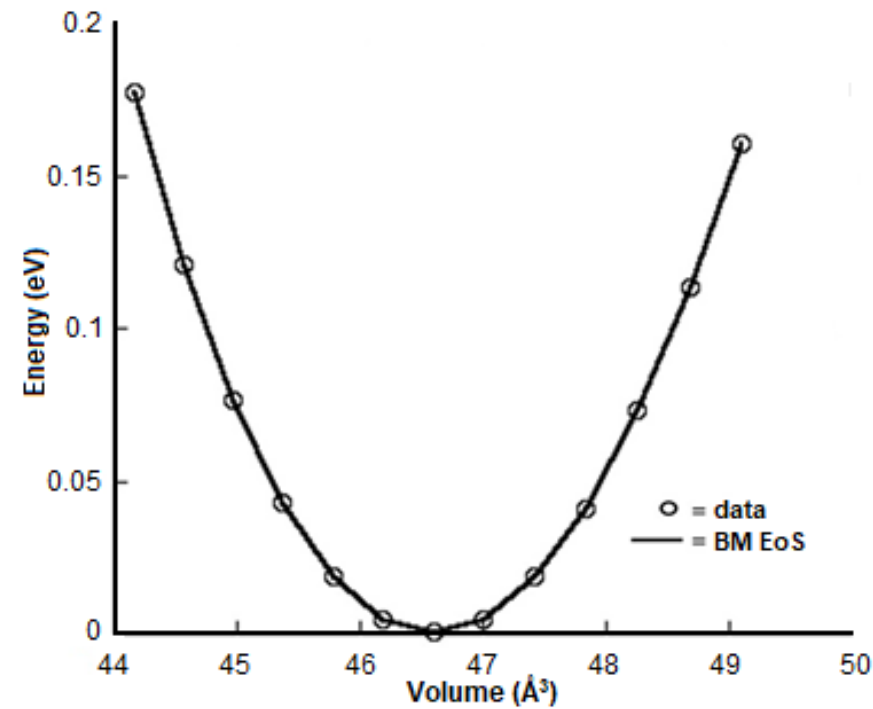

Fig 1. A fit to the Birch-Murnaghan equation of states of the calculated energies with respect to the cell volumes. The energies are relative energies where the energy of the optimized geometry is set to be zero

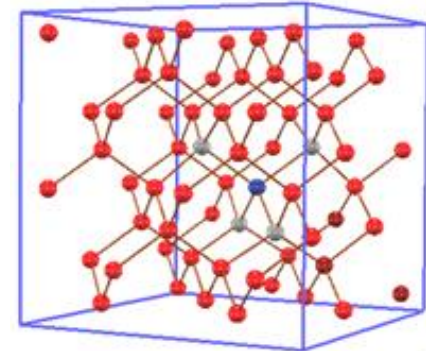

(a)

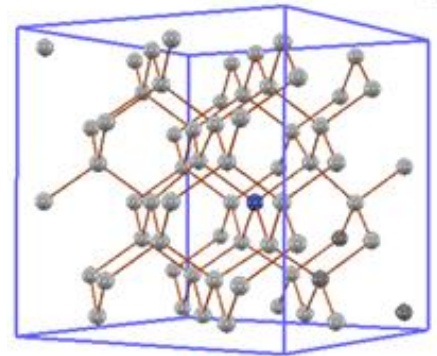

(c)

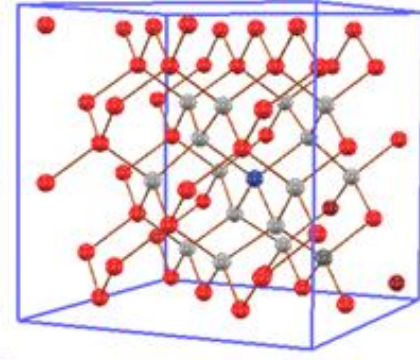

(b)

$$
\begin{aligned}
& \text { Unrelaxed C } \\
& \text { Relaxed C }
\end{aligned}
$$

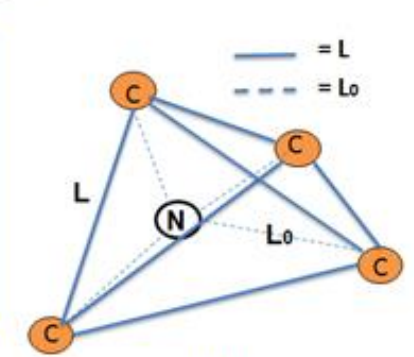

(d)

Fig 2. Geometry of substitutional nitrogen in diamond: (a) relaxation by considering up to first-nearest neighbor atoms $\left(A_{1}\right),(b)$ up to second-nearest neighbor atoms $\left(A_{2}\right)$, and $(c)$ full relaxation $\left(A_{3}\right)$. The blue ball is a nitrogen atom, the light-grey and the red balls are carbon atoms which are allowed and unallowed to move, respectively. The defect geometry formed by four nearest-neighbor atoms are also shown (d), where $\mathrm{L}_{0}$ and $\mathrm{L}$ are distances between $\mathrm{N}-\mathrm{C}$ and between two first-nearest neighbor carbon atoms 
second-nearest neighbor atoms (Fig. 2(b)), and full relaxations considering all atoms (Fig. 2(c)), respectively. The local defect geometry is shown in Fig. 2(d). As for the interstitial defects, some calculations of possible configurations were performed with initial configurations dubbed as $B_{1}, B_{2}, B_{3}$, and $B_{4}$, which are bond-center Fig. 3(a), antibonding (Fig. 3(b)), hexagonal (Fig. 3(c)), and octahedral sites Fig. 3(d), respectively. In these calculations, all atoms were relaxed in the supercell until the atomic forces are less than $5.0 \times 10^{-3}$ $\mathrm{eV} / \AA$. The geometry optimizations were conducted at constant volume with the length of unit cell of $3.59 \AA$.

Formation energies for each defect configuration were calculated by using the following equations $[13,23$ 24]:

$E_{f}(S)=E_{d}-\left(E_{p}-\mu_{C}+\mu_{N}\right)$

for the substitutional, and

$E_{f}(I)=E_{d}-\left(E_{p}-\mu_{N}\right)$

for the interstitial. $E_{p}$ and $E_{d}$ are total energies of the perfect and defective supercells, respectively, while $\mu \mathrm{c}$ and $\mu_{\mathrm{N}}$ are chemical potentials, which are approximated as the total energy of an individual atom of carbon and nitrogen atom, respectively. The defect volume changes are also calculated as follows:

$\Delta \mathrm{V}=\frac{\mathrm{V}_{\mathrm{f}}-\mathrm{V}_{0}}{\mathrm{~V}_{0}}$

where $V_{f}$ and $V_{0}$ are the defect volumes of the tetrahedral (Fig. 2(d)) formed by four nearest-neighbor atoms of the relaxed and ideal (unrelaxed) geometries, respectively (Fig. 2(b)).

\section{RESULT AND DISCUSSION}

\section{Substitutional Defect}

The formation energies of the substitutional defect are calculated by using Eq. 1. The calculations are carried out with respect to the k-point mesh grids for $k_{M P}$ $=1,2,4$, and 6 . The calculated formation energies for various $\mathrm{k}$-point values and the relaxation types are given in Table 1 . The formation energy differences between $A_{1}$ and $A_{3}$ vary in the small range of $0.18-0.20 \mathrm{eV}$, while those between $A_{2}$ and $A_{3}$ is very small, which is less than $0.10 \mathrm{eV}$. As for the calculated formation energies for the relaxation type $A_{3}\left(E_{f}{ }^{A 3}\right)$ with respect to $k M P$, the energy difference between $\mathrm{k}_{M P}=2$ and $\mathrm{k}_{M P}=4$ is only $0.20 \mathrm{eV}$ and that between $\mathrm{k}_{\mathrm{MP}}=4$ and $\mathrm{k}_{\mathrm{MP}}=6$ is close to zero, which is only $7.0 \mathrm{meV}$. Therefore, it is concluded that the formation energy converges at the relaxation by considering up to the second nearest-neighbor atoms and by using $k$-point grid $\mathrm{kMP}_{\mathrm{M}}=4$.

Once the optimized geometry of the defective diamond is reached, the bond distances between the

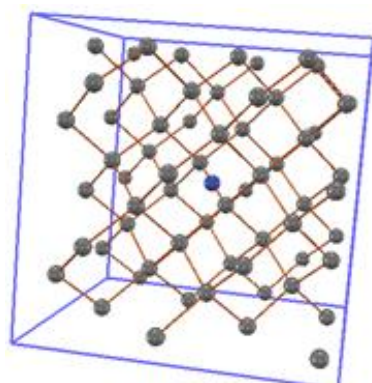

(a)

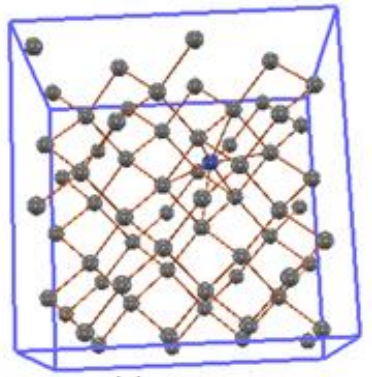

(c)

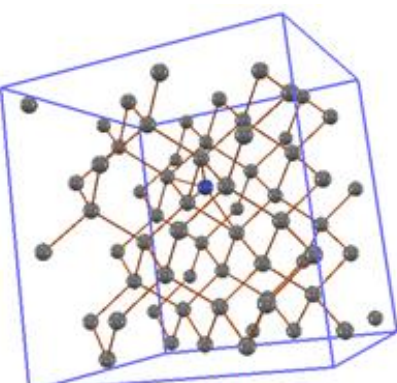

(b)

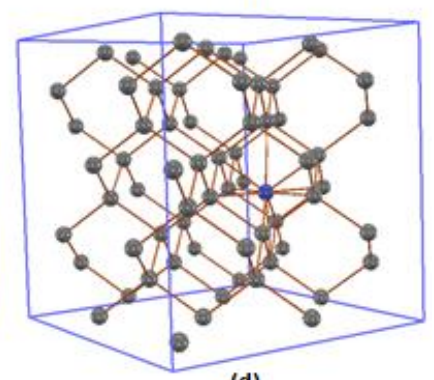

(d)
Fig 3. Geometries of interstitial nitrogen in diamond: (a) bond-center $\left(B_{1}\right)$, (b) antibonding $\left(B_{2}\right)$, and (c) hexagonal $\left(B_{3}\right)$, and octahedral sites $\left(B_{4}\right)$. In these calculations, all atoms are relaxed

Table 1. Calculated formation energies with respect to $\mathrm{k}_{\mathrm{MP}}$ and the relaxation types by using the 64-sites supercell. $E_{f}{ }^{A 1}, E_{f}{ }^{A 2}$, and $E_{f}{ }^{A 3}$ are the formation energy for relaxation type $A_{1}, A_{2}$, and $A_{3}$, respectively

\begin{tabular}{lllc}
\hline $\mathrm{k}_{\mathrm{MP}}$ & $\mathrm{E}_{\mathrm{f}}^{\mathrm{A} 1}(\mathrm{eV})$ & $\mathrm{E}_{\mathrm{f}}^{\mathrm{A} 2}(\mathrm{eV})$ & $\mathrm{E}_{\mathrm{f}}^{\mathrm{A} 3}(\mathrm{eV})$ \\
\hline 1 & 12.03 & 11.91 & 11.83 \\
2 & 11.38 & 11.18 & 11.09 \\
4 & 11.06 & 10.97 & 10.89 \\
6 & 11.08 & 11.18 & 10.89 \\
\hline
\end{tabular}

Table 2. Calculated formation energies and defect properties with respect to $\mathrm{K}_{\mathrm{MP}}$ by using the 64-sites supercell. $L_{0}, L$, and $\Delta V$ refer to Fig. 1 , which are $L_{0}$ is a distance between the nitrogen atom and its adjacent carbon and $L$ is a distance between nearest-neighbor atoms in the relaxed geometries. Whereas $\mathrm{L}_{\mathrm{a} 0}$ and $\mathrm{L}_{b 0}$ are distances in the ideal geometries, respectively

\begin{tabular}{|c|c|c|c|c|}
\hline KMP & Relaxation & $\begin{array}{c}L_{a}(\AA) \\
L_{a 0}=1: 56\end{array}$ & $\begin{array}{c}L_{b}(\AA) \\
L_{b 0}=2: 54\end{array}$ & $\Delta \mathrm{V}(\%)$ \\
\hline \multirow{3}{*}{1} & $A_{1}$ & 1.68 & 2.75 & 25.74 \\
\hline & $A_{2}$ & 1.71 & 2.79 & 31.30 \\
\hline & $A_{3}$ & 1.72 & 2.82 & 35.54 \\
\hline \multirow{3}{*}{2} & $A_{1}$ & 1.71 & 2.79 & 31.91 \\
\hline & $A_{2}$ & 1.73 & 2.83 & 37.03 \\
\hline & $A_{3}$ & 1.75 & 2.86 & 41.92 \\
\hline \multirow{3}{*}{4} & $A_{1}$ & 1.68 & 2.75 & 31.10 \\
\hline & $A_{2}$ & 1.73 & 2.82 & 36.13 \\
\hline & $A_{3}$ & 1.70 & 2.78 & 30.56 \\
\hline \multirow{3}{*}{6} & $A_{1}$ & 1.68 & 2.75 & 31.49 \\
\hline & $\mathrm{A}_{2}$ & 1.73 & 2.82 & 36.53 \\
\hline & $A_{3}$ & 1.75 & 2.85 & 41.27 \\
\hline
\end{tabular}


nitrogen atom and its four nearest-neighbor atoms $\left(\mathrm{L}_{\mathrm{a}}\right)$ are calculated. The four distances, $\mathrm{L}_{\mathrm{a}}$, are elongated with the same lengths. Thus, the distances between the nearest-neighbor atoms $\left(L_{b}\right)$ also increase. As a consequence, the bonds between the nitrogen and carbon atoms are weak. The optimized geometry of the substitutional configuration is shown in Fig. 4(a). The length of $L_{a}$ increases by 7.90 to $12.40 \%$ from the ideal distances $\left(L_{a 0}=1: 56 \AA\right)$. Next, the defect volume changes $(\Delta \mathrm{V})$ are calculated from the six identic ideal and relaxed distances between the four neighbor atoms, $\mathrm{Lbo}_{b}$ and $\mathrm{Lb}_{b}$, respectively. It is found that $(\Delta \mathrm{V})$ has a positive sign for all of the calculations, indicating that the geometry distortion occurs in the final optimization process following an outward relaxation (Table 2). The relaxed defect volumes increase in the range of $30-42 \%$ from the ideal ones.

Lombardi et al. [16] showed that the geometry distortion follows an outward relaxation. They found that the distance between the nitrogen atom and its first nearest-neighbor atom ( $\mathrm{N}-\mathrm{C}$ bondlength) increases by $28 \%$ from the ideal distance (C-C bondlength). Deak et al. [17] also found the outward relaxation, and the N-C bond distance was elongated by $32 \%$. Our results are in agreement with those of these previous DFT studies, e.g., the outward relaxation occurs in the optimized geometry. Our calculated $\mathrm{N}-\mathrm{C}$ bondlengths in the optimized geometry differ by up to $20 \%$ from the ideal ones.

\section{Interstitial Defect}

To search the most stable configurations of the nitrogen-doped diamond, the formation energies of some possible configurations are calculated. In these calculations, four initial configurations are simulated, which are $\mathrm{B}_{1}$ (bond-center), $\mathrm{B}_{2}$ (antibonding), $\mathrm{B}_{3}$ (hexagonal), and $\mathrm{B}_{4}$ (octahedral) as shown in Fig. 3(a-d).
In the optimized structure of the initial $\mathrm{B}_{1}$ configuration, the bond between two carbon atoms, where the nitrogen was initially placed, breaks and the nitrogen atom makes a short bond of $1.46 \AA$, which is shorter than the ideal C-C bond, with one carbon atom (Fig. 4(b)). The calculated formation energy is $32.52 \mathrm{eV}$. The optimized geometry of the $B_{2}$ is that the nitrogen atom makes two strong $\mathrm{N}-\mathrm{C}$ bonds with the average bondlengths of $1.31 \AA$ (Fig. 4(c)) and makes one low NC bond of $1.91 \AA$.

The calculated formation energy is close to the $B_{2}$ configuration, which is $32.18 \mathrm{eV}$. As for the $\mathrm{B}_{3}$ and $\mathrm{B}_{4}$,

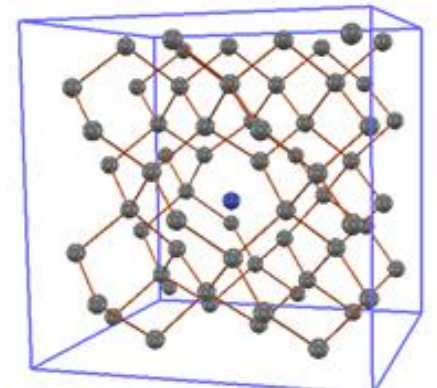

(a)

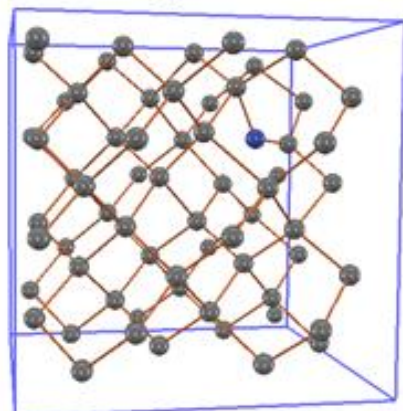

(c)

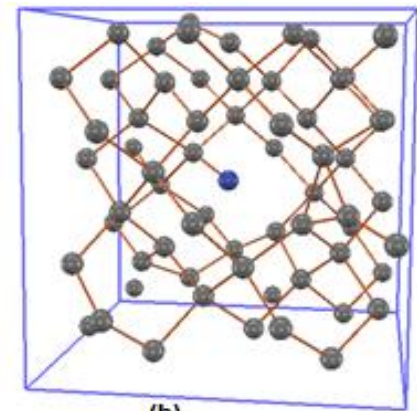

(b)

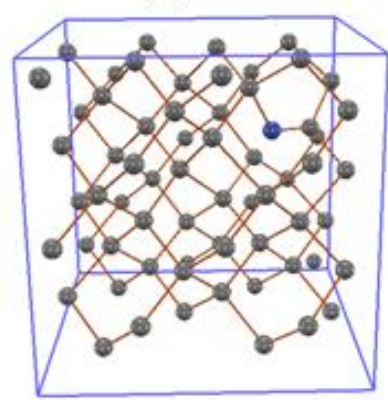

(d)
Fig 4. The optimized geometries of (a) substitutional $\left(A_{3}\right)$, (b) $B_{1}$, (c) $B_{2}$, and (d) $B_{3}$ and $B_{4}$ configurations (a) Perfect

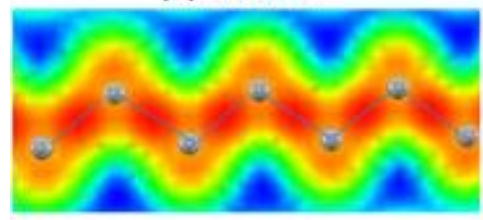

(c) Octahedral $\left(\mathrm{B}_{4}\right)$ (b) Substitutional $\left(\mathrm{A}_{3}\right)$
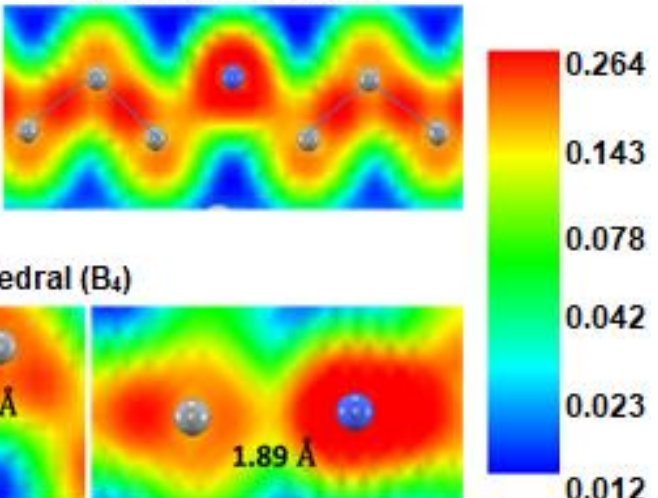

Fig 5. Charge density distributions in the (a) perfect supercell, (b) substitutional configuration $\left(A_{3}\right)$, and (c) octahedral configuration $\left(\mathrm{B}_{4}\right)$. The color bar unit is e/(a.u. $)^{3}$ 
the same geometry is found that the nitrogen atom is bonded by two carbon atoms with the strong bond of 1.29 and $1.31 \AA$ (Fig. 4(d)). Another bond is a lower N-C bond of $1.89 \AA$. Both configurations are more stable than $B_{1}$ and $B_{2}$ shown by smaller formation energy of 21.88 $\mathrm{eV}$. However, the most stable configuration is the substitutional having the lowest formation energy of $10.89 \mathrm{eV}$.

\section{Charge Density Distribution}

Charge density distributions are modeled to show the bonding strength formed by the nitrogen defect (Fig. $5)$. The bond charge density in the $A_{3}$ configuration is lower compared to that in the perfect crystal (Fig. 5(a)). The increase of the defect volume is caused by the Coulomb repulsion between electrons of the nitrogen and those of four nearest carbon atoms, which results a weak bond shown by a low bond charge density in. Fig. 5 (b). The $B_{4}$ configuration results two bonds having high bond charge densities and one bond with very low bond density (Fig. 5(c)). This very low bond charge density is the origin of the $\mathrm{B}_{4}$ configuration instability compared to the $A_{3}$ one.

\section{CONCLUSION}

The DFT calculations on the formation energy of the substitutional and interstitial configurations in defective diamond have been carried out. It was found that the most stable configuration is the substitutional configuration with the converged formation energy of $10.89 \mathrm{eV}$. As for the geometry distortion, the relaxed defect volumes are outward distorted up to $42 \%$.

\section{ACKNOWLEDGEMENT}

This work was supported by a research grant of PDUPT (Penelitian Dasar Unggulan Perguruan Tinggi) No. 2451/UN1.P.III/DIT-LIT/LT/2017 and No. 162/UN1/DITLIT/DIT-LIT/LT/2018, from the General Directorate of Higher Education (DIKTI), Ministry of Research, Technology and Higher Education of the Republic of Indonesia. This research was also supported by the BOPTN-2017/2018 grant from Universitas Gadjah Mada. The computations were performed using highperformance computing at LIPI (Lembaga IImu Pengetahuan Indonesia) and DSSDI (Direktorat Sistem dan Sumber Daya Informasi) Universitas Gadjah Mada.

\section{REFERENCES}

[1] Walker, J., 1979, Optical absorption and luminescence in diamond, Rep. Prog. Phys., 42, 1605-1658.
[2] Abbaschian, R., Zhu, H., and Clarke, C., 2005, High pressure-high temperature growth of diamond crystals using split sphere apparatus, Diamond Relat. Mater., 14 (11-12), 1916-1919.

[3] Poferl, D.J., Gardner, N.C., and Angus, J.C., 1973, Growth of boron-doped diamond seed crystals by vapor deposition, J. Appl. Phys., 44, 1428.

[4] Fu, K.C., Santori, C., Barclay, P.E., Rogers, L.J., Manson, N.B., and Beausoleil, R.G., 2009, Observation of the dynamic Jahn-Teller effect in the excited states of nitrogen-vacancy centers in diamond, Phys. Rev. Lett., 103 (25), 256404.

[5] Kaiser, W., and Bond, W.L., 1959, Nitrogen, a major impurity in common type I diamond, Phys. Rev., 115 (4), 857-863.

[6] Golter, D.A., Oo, T., Amezcua, M., Stewart, K.A., and Wang, H., Optomechanical quantum control of a nitrogen-vacancy center in diamond, Phys. Rev. Lett., 116 (14), 143602.

[7] Iwasaki, T., Ishibashi, F., Miyamoto, Y., Doi, Y., Kobayashi, S., Miyazaki, T., Tahara, K., Jahnkae, K.D., Rogers, L.J., Naydenov, B., Jelezko, V., Yamasaki, S., Nagamachi, S., Inubushi, T., Mizuochi, N., and Hatano, M., 2015, Germaniumvacancy single color centers in diamond, Sci. Rep., 5, 12882.

[8] Bouwmeester, D., Pan, J.W., Mattle, K., Eibl, M., Weinfurter, H., and Zeilinger, A., 1997, Experimental quantum teleportation, Nature, 390, 575-579.

[9] Gisin, N., Ribordy, G., Tittel, W., and Zbinden, H., 2002, Quantum cryptography, Rev. Mod. Phys., 74, 145-195.

[10] Makhov, D.V., and Lewis, L.J., 2004, Stable fourfold configurations for small vacancy clusters in silicon from ab initio calculations, Phys. Rev. Lett., 92, 255504.

[11] Sholihun, Ishii, F., and Saito, M., 2016, Firstprinciples calculations of multivacancies in germanium, Jpn. J. Appl. Phys., 55 (1), 011301.

[12] Fitriana, A.S., Pranowo, H.D., and Purwono, B., 2016, Chalcone based colorimetric sensor for anions: experimental and TD-DFT study, Indones. J. Chem., 16 (1), 80-86.

[13] Śpiewak, J.P., Vanhellemont, J., and Kurzydłowski, K.J., 2011, Improved calculation of vacancy properties in $\mathrm{Ge}$ using the HeydScuseria-Ernzerhof range-separated hybrid functional, J. Appl. Phys., 110, 063534.

[14] Childress, L., Dutt, M.V.G., Taylor, J.M., Zibrov, A.S., Jelezko, F., Wrachtrup, J., Hemmer, P.R., and Lukin, M.D., 2006, Coherent dynamics of coupled electron and nuclear spin qubits in diamond, Science, 314, 281-285. 
[15] Lee, S.Y., Widmann, M., Rendler, T., Doherty, M.W., Babinec, T.M., Yang, S., Eyer, M., Siyushev, P., Hausmann, B.J.M., Loncar, M., Bodrog, Z., Gali, A., Manson, N.B., Feder, H., and Wrachtup, J., 2013, Readout and control of a single nuclear spin with a metastable electron spin ancilla, Nat. Nanotechnol., 8, 487-492.

[16] Lombardi, E.B., Mainwood, A., Osuch, K., and Reynhardt, E.C., 2003, Computational models of the single substitutional nitrogen atom in diamond, J. Phys. Condens. Matter, 15 (19), 3135-3149.

[17] Deak, P., Aradi, B., Kaviabi, M., Frauenheim, T., and Gali, A., 2014, Formation of NV centers in diamond: A theoretical study based on calculated transitions and migrations of nitrogen and vacancy related defects, Phys. Rev. B, 89, 075203.

[18] PHASE, http://www.ciss.iis.u-tokyo.ac.jp/dl/index.php.

[19] Birch, F., 1947, Finite elastic strain of cubic crystal, Phys. Rev., 71 (11), 809-824.
[20] Zhuravlev, K., 2007, PbSe vs. CdSe: Thermodynamic properties and pressure dependence of the band gap, Physica B, 394 (1), $1-7$.

[21] Staroverov, V.N., Scuseria, G.E., Tao, J., and Perdew, J.P., 2008, Erratum: Tests of a ladder of density functionals for bulk solids and surfaces, Phys. Rev. B, 78 (23), 239907.

[22] Haas, P., Tran, F., and Blaha, P., 2009, Calculation of the lattice constant of solids with semilocal functionals, Phys. Rev. B, 79, 085104.

[23] Corsetti, F., and Mostofi, A.A., 2011, System-size convergence of point defect properties: The case of silicon vacancy, Phys. Rev. B, 84, 035209.

[24] Probert, M.I.J., and Payne, M.C., 2003, Improving the convergence of defect calculations in supercells: An ab initio study of the neutral silicon vacancy, Phys. Rev. B, 67, 075204. 